\title{
Growth Inhibition of Candida albicans in the Presence of Antiserum Elicited in Rabbits by Mannan-Protein Conjugate
}

\author{
Eva Machová* and Slavomír Bystrický \\ Institute of Chemistry, Slovak Academy of Sciences, Dúbravská cesta 9, 84538 Bratislava, \\ Slovak Republic. Fax: + 421-2-5941022. E-mail: chememch@savba.sk \\ * Author for correspondence and reprint requests \\ Z. Naturforsch. 63c, 909-912 (2008); received May 16/June 24, 2008 \\ Antifungal properties of rabbit antiserum prepared by immunization are reported. The \\ immunization was done by a chemically prepared conjugate consisting of Candida albicans \\ (serotype A) surface mannan and human serum albumin. Addition of rabbit antiserum to \\ D-glucose medium inoculated with $C$. albicans effectively inhibited its growth. Moreover, \\ C. albicans cells treated with rabbit antiserum revealed the entire loss of viability (expressed \\ as decreased mitochondrial dehydrogenase activity). No growth of treated cells on an agar \\ plate was observed. The results confirmed that the mannan-protein conjugate could be con- \\ sidered as an effective component of perspective vaccine.
}

Key words: C. albicans Mannan-Protein Conjugate, Rabbit Antiserum, Growth Inhibition

\section{Introduction}

Candida albicans surface mannan conjugated to a protein carrier is immunogenic in rabbits and elicits booster response of IgG serum level (Han et al., 1999; Bystrický et al., 2003). In our previous paper, the antifungal quality of the antisera was documented by the $C$. albicans growing inhibition test (Bystrický et al., 2003). The classical view of antibody-mediated immunity is attributed to their indirect functions, such as opsonic and complement-activating properties (Casadevall and Pirofski, 2004). In the past years, the direct antimicrobial activities of antibodies were also published. $\mathrm{IgM}$ and $\mathrm{IgG}$ antibodies against Borrelia burgdorferi surface proteins damage the proteins and the impairment of the bacterial coat leads to its death (Connolly et al., 2004). It is believed that serum antibodies play a key role in the protection against candidiasis (Brena et al., 2007). 40 years ago, Mourad and Friedman (1968) examined the effect of passive immunization against intravenously applied C. albicans on mice. The experiments indicated that passive immunization confers demonstrable protection, $33 \%$ of the animals survived the entire period of observation. Casanova et al. (1990) found that Fab fragments from a monoclonal antibody against a germ-tube mannoprotein block the transition of yeast to mycelium in $C$. albicans. Moragues et al. (2003) described a monoclonal antibody directed against $C$. albicans cell wall mannoprotein which exerted an antifungal activity through the three mechanisms - interference with adherence, inhibition of germination, and direct candidacidal activity. The comprehensive role of antibodies against yeasts is still not clear.

Here we try to shed light on the quality of antiserum from rabbits immunized with conjugate consisting of C. albicans surface mannan and human serum albumin.

\section{Experimental}

\section{Microorganism}

The strain C. albicans CCY 29-3-32 (serotype A) was from Culture Collection of Yeasts (CCY), Institute of Chemistry, Slovak Academy of Sciences, Bratislava, Slovakia.

\section{Preparation of conjugate and immunization}

C. albicans mannan-human serum albumin (mannan-HSA) conjugate was prepared and characterized as described elsewhere (Bystrický et al., 2000, 2003). Immunization of rabbits with mannan-human serum conjugate as well as with mannan alone was proceeded intravenously (i.v.) five times in intervals of one week, no adjuvant was used. Antisera were stored at $-20^{\circ} \mathrm{C}$. Inactivation of complement in rabbit antisera was realized at $56{ }^{\circ} \mathrm{C}$ during $30 \mathrm{~min}$ as recommended by Knudtson and Fetters (1990). 
Cultivation of C. albicans in $2 \%$ D-glucose medium

C. albicans grown on slant agar was used for the preparation of a stock C. albicans suspension (3.02 $\cdot 10^{6}$ cells in $1 \mathrm{~mL}$ of sterile water). The composition of $2 \%$ D-glucose medium was as follows: $2 \mathrm{~g}$ D-glucose, $0.05 \mathrm{~g} \mathrm{KH}_{2} \mathrm{PO}_{4}, 0.1 \mathrm{~g} \mathrm{MgSO}_{4}, 0.3 \mathrm{~g}$ $\left(\mathrm{NH}_{4}\right)_{2} \mathrm{SO}_{4}, 0.5 \mathrm{~g}$ yeast autolysate and $10 \mu \mathrm{L}$ of microelement solution $\left(2.4 \mathrm{~g} \mathrm{FeCl}_{3} \cdot 6 \mathrm{H}_{2} \mathrm{O}, 2.0 \mathrm{~g}\right.$ $\mathrm{Na}_{2} \mathrm{MoO}_{4}, 1.2 \mathrm{~g} \mathrm{ZnSO}_{4}, 1.8 \mathrm{~g} \mathrm{MnCl}_{2} \cdot 4 \mathrm{H}_{2} \mathrm{O}, 0.05 \mathrm{~g}$ $\mathrm{KI}, 0.4 \mathrm{~g} \mathrm{CuSO}_{4}, 1.2 \mathrm{~g} \mathrm{H}_{3} \mathrm{BO}_{3}$, filled to $100 \mathrm{~mL}$ with distilled water). The yeast cultivation was performed in L-shaped tubes containing $85 \mu \mathrm{L}$ of stock $C$. albicans suspension $\left(2.57 \cdot 10^{5}\right.$ cells $)$ and $7 \mathrm{~mL}$ of $2 \%$ D-glucose medium on a reciprocal shaker (120 oscillations per min) at $27^{\circ} \mathrm{C}$ in triplicate.

\section{Growth protocols}

1) $100 \mu \mathrm{L}$ of rabbit antiserum obtained after the $5^{\text {th }}$ immunization (after complement inactivation) were added to $2 \%$ D-glucose medium with $85 \mu \mathrm{L}$ of stock C. albicans suspension. 2) $300 \mu \mathrm{L}$ of stock C. albicans suspension with $250 \mu \mathrm{L}$ of complement inactivated rabbit antiserum were shaken during $3 \mathrm{~h}$ at room temperature and stored overnight at $4{ }^{\circ} \mathrm{C}$. The suspension was centrifuged at $1500 \times g$, and treated C. albicans cells were twice washed with PBS buffer and inoculated to $2 \%$ D-glucose medium. 3) $1^{\text {st }}$ negative control: $100 \mu \mathrm{L}$ of rabbit preimmune serum (after complement inactivation) were added to $2 \%$ D-glucose medium with $85 \mu \mathrm{L}$ of stock C. albicans suspension. 4) $2^{\text {nd }}$ negative control: $100 \mu \mathrm{L}$ of rabbit antiserum (after complement inactivation) were added to $2 \%$ D-glucose medium with $85 \mu \mathrm{L}$ of stock C. albicans suspension. 5) Positive control: $85 \mu \mathrm{L}$ of stock C. albicans suspension were added to $2 \%$ D-glucose medium. In all experiments the growth of $C$. albicans was monitored by measuring the absorbance at $660 \mathrm{~nm}$.

\section{Viability test}

The colorimetric assay of cellular viability utilizes XTT \{2,3-bis (2-methoxy-4-nitro-5-sulfophenyl-5-[(phenylamino)carbonyl]- $2 H$-tetrazolium hydroxide\} (Sigma) which is reduced by mitochondrial dehydrogenases of metabolically active yeast cells to a dark blue formazan product (Kuhn et al., 2003). The different volumes of C. albicans suspensions $(0.1 \mathrm{~mL}, 0.3 \mathrm{~mL}, 0.5 \mathrm{~mL})$ with $0.3 \mathrm{~mL}$ of rabbit antisera were incubated on a reciprocal shaker for $1 \mathrm{~h}$ at room temperature. The treated C. albicans cells were collected at $1500 \times g$ for $10 \mathrm{~min}$, sediments were twice washed with PBS buffer and diluted to final volumes of $1.2 \mathrm{~mL}$. The colorimetric reagent, $0.2 \mathrm{mg}$ of XTT in $200 \mu \mathrm{L}$ PBS and $0.02 \mathrm{mg}$ of phenazine methosulfate (PMS, Sigma) in $100 \mu \mathrm{L}$ PBS, was added and the reaction mixture was incubated for $1.5 \mathrm{~h}$ at $37^{\circ} \mathrm{C}$. The suspension was centrifuged at $4000 \times g$ (supernatant 1$)$. Formazan retained in cell pellets was released by $100 \%$ dimethylsulfoxide and the suspension was again centrifuged (supernatant 2). After collection of both supernatants, the produced formazan was observed at $492 \mathrm{~nm}$ (Shimadzu 1240 UV-mini spectrophotometer). Autoclaved C. albicans cells with damaged metabolic functions were used as control killed yeast sample. The assays were repeated in four biologically independent samples.

\section{Results and Discussion}

\section{Growth of C. albicans in the presence of rabbit antiserum}

Nowadays, the main trend in the preparation of vaccines against pathogenic bacteria and yeasts is chemical conjugation of surface polysaccharide antigens with carrier protein (Lucas et al., 2005). Such conjugates overcome the immunological deficiency of the saccharide antigen alone and greatly extend the vaccine efficacy. Concerning Candida pathogens, mannan polysaccharide is the most exposed surface antigen determining their immunological properties (Cutler, 2005).

In our previous paper, $C$. albicans antiserum prepared by i.v. immunization of the rabbit with the prepared mannan-HSA conjugate exhibited growth inhibition zones on agar plates inoculated with $C$. albicans. Besides this antiserum contained significantly higher levels of anti-mannan $\mathrm{IgG}$ antibodies compared with hyperimmune serum. No adjuvant was used in the immunization experiments (Bystrický et al., 2003).

Here, addition of $100 \mu \mathrm{L}$ of rabbit antiserum (after complement inactivation) completely in hibited the growth of C. albicans in $2 \%$ D-glucose medium during $72 \mathrm{~h}$ of cultivation (Fig. 1). Also, C. albicans cells were incubated for $3 \mathrm{~h}$ with $250 \mu \mathrm{L}$ of rabbit antiserum and then inoculated in $2 \%$ D-glucose medium (Fig. 1) as well as plated in agar, and no growth of $C$. albicans was observed. Contrary to these results, $100 \mu \mathrm{L}$ of preimmune rabbit 


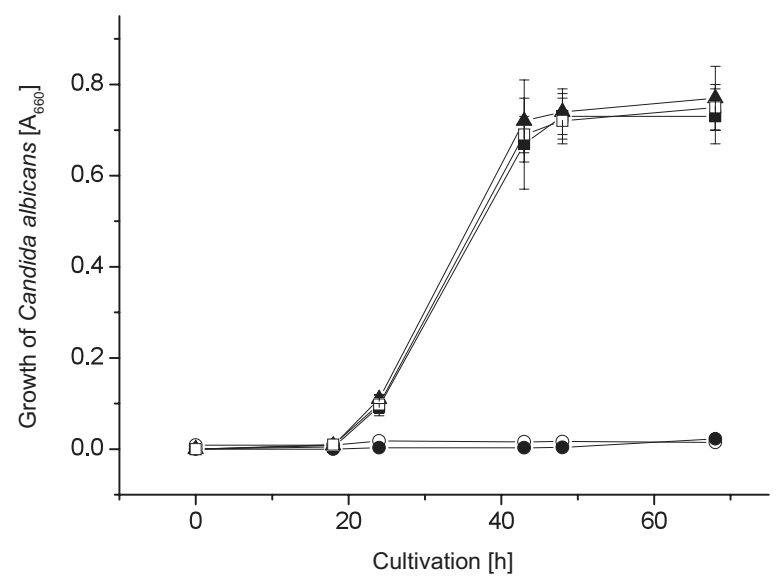

Fig. 1. Growth curves of C. albicans in $2 \%$ D-glucose medium during $72 \mathrm{~h}$. (O) Addition of $100 \mu \mathrm{L}$ rabbit antiserum to $C$. albicans inoculated in the growth medium; (O) C. albicans cells treated with $250 \mu \mathrm{L}$ rabbit antiserum for $3 \mathrm{~h}$ and then inoculated into the growth medium; ( $\mathbf{\square})$ addition of rabbit preimmune serum to C. albicans inoculated in the growth medium as $1^{\text {st }}$ negative control; ( $\boldsymbol{\Delta})$ addition of rabbit antiserum to C. albicans inoculated in the growth medium as $2^{\text {nd }}$ negative control; $(\square)$ native $C$. albicans inoculated in the growth medium as positive control. Error bars represent standard deviation of the mean value $(n=3)$.

serum as well as $100 \mu \mathrm{L}$ of rabbit antiserum used as negative controls did not influence the growth of C. albicans (Fig. 1). Native C. albicans cells were used as positive control of growth (Fig. 1).

\section{Viability of C. albicans in the presence of rabbit antiserum}

The viability of $C$. albicans cells was monitored using the XTT colorimetric assay: the production of formazan was evident in native C. albicans cells having functional mitochondrial dehydrogenases. The amount of produced formazan was proportional to the increasing amounts of native C. albicans $(0.1-0.5 \mathrm{~mL})$ (Fig. 2, columns A). In contrast, C. albicans treated with rabbit antiserum showed markedly decreased mitochondrial activity (Fig. 2, columns B). Autoclaved C. albicans (15 $\mathrm{min}$ at $120^{\circ} \mathrm{C}$ ) used as killed cells did not show mitochondrial dehydrogenase activity (Fig. 2, columns C).

Microscopic observation of $C$. albicans treated $3 \mathrm{~h}$ with rabbit antiserum showed the formation of clusters of yeast cells typical for a behaviour under stress conditions.

Evidently, the observed antifungal activity of rabbit antiserum is related to an increased level of

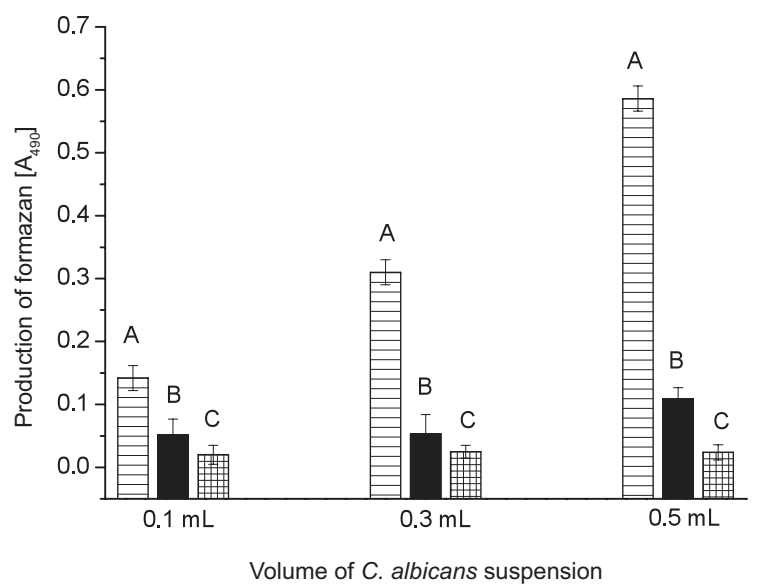

Fig. 2. Viability of C. albicans as a function of different amounts of yeast: $0.1,0.3$ and $0.5 \mathrm{~mL}$ of $C$. albicans suspension. (A) Native C. albicans; (B) treated C. albicans cells $-3 \mathrm{~h}$ incubation with rabbit antiserum; (C) negative control - C. albicans autoclaved $15 \mathrm{~min}$ at $120^{\circ} \mathrm{C}$. Error bars represent standard deviation of the mean value $(n=4)$.

the protective anti-mannan IgG antibodies in the serum (Bystrický et al., 2003). It is known that antibodies against Candida antigens are commonly present in the sera due to the colonization of mucosa with Candida sp. or subclinical disease occurrence. Cutler (2005) supposed that C. albicans induces highly complex pools of heterogeneous polyclonal antibody responses. Within the pool, the protective antibodies may not be present in sufficient titer to effect antifungal protection. We propose that immunization with the synthetically prepared mannan-protein conjugate would elicit a high level of protective antibodies. Based on the presented observations we presume that the protective effect of antibodies induced by the mannan-protein conjugate is rendered by direct blocking of vital functions of C. albicans rather than any complement-dependent lysis. The presented results support the notion that the Candida surface polysaccharide-based conjugate would be a perspective candidate for preventive immunomodulation treatment (Cassone et al., 2007).

\section{Acknowledgements}

This work was supported by the Grant Agency of Slovak Academy of Sciences (VEGA No. 2/7029/27) and APVT Agency (No. 51-015902). We thank Bc. B. Alfóldyová for excellent technical assistance. 
Brena S., Omaetxebarria M. J., Elguezabal N., Cabezas J., Moragues M. D., and Pontón J. (2007), Fungicidal monoclonal antibody C7 binds to Candida albicans Als3. Infect. Immun. 75, 3680-3682.

Bystrický S., Machová E., Bartek P., Kolarova N., and Kogan G. (2000), Conjugation of yeast mannans with protein employing cyanopyridinium agent (CDAP) an effective route of antifungal vaccine preparation. Glycoconjugate J. 17, 677-680.

Bystrický S., Paulovičová E., and Machová E. (2003), Candida albicans mannan-protein conjugate as vaccine candidate. Immunol. Lett. 85, 251-255.

Casadevall A. and Pirofski L. A. (2004), New concepts in antibody-mediated immunity. Infect. Immun. 72, 6191-6196.

Casanova M., Martinez J. P., and Chaffin W. L. (1990), Fab fragments from a monoclonal antibody against a germ-tube mannoprotein blocked the yeast-to mycelium transition in C. albicans. Infect. Immun. 58, 3810-3812.

Cassone A., De Bernardis F., and Santoni G. (2007), Anticandidal immunity and vaginitis: novel opportunities for immune intervention. Infect. Immun. 75, 4675-4686.

Connolly S. E., Thanassi D. G., and Benach J. L. (2004), Generation of a complement-independent bactericidal
IgM against a relapsing fever Borrelia. J. Immunol. 172, $1191-1197$.

Cutler J. E. (2005), Defining criteria for anti-mannan antibodies to protect against candidiasis. Curr. Mol. Med. 5, 383-392.

Han Y., Ulrich M. A., and Cutler J. E. (1999), Candida albicans mannan extract-protein conjugates induce a protective immune response against experimental candidiasis. J. Infect. Dis. 79, 1477-1484.

Knudtson W. U. and Fetters M. (1990), The effect of heat inactivation on agglutinating antibody titers to Leptospira interrogans. J. Vet. Diagn. Invest. 2, 149150.

Kuhn D. M., Balkis M., Chandra J., Mukherjee P. K., and Ghannoum M. A. (2003), Uses and limitations of the XTT assay in studies of Candida growth and metabolism. J. Clin. Microbiol. 41, 506-508.

Lucas A. H., Apicella M. A., and Taylor C. E. (2005), Carbohydrate moieties as vaccine candidates. Clin. Inf. Dis. 41, 705-712.

Moragues M. D., Omaetxbarria M. J., Elguezabal N., Sevilla M. J., Conti S., Polonelli L., and Pontón J. (2003), A monoclonal antibody directed against a $C$. albicans cell wall mannoprotein exerts three anti- $C$. albicans activities. Infect. Immun. 71, 5273-5279.

Mourad S. and Friedman L. (1968), Passive immunization of mice against Candida albicans. Sabouraudia 6, $103-105$. 